\title{
Space Liability Insurance: Concerns and Way Forward
}

\author{
By Sandeepa Bhat B.
}

\begin{abstract}
With the enormous increase in private space activities, the States across the globe have found difficulties in regulating them and protecting common interest in outer space. As the existing international space law imposes liability for any damage caused by private space activities to respective launching State/s, one of the moot questions before the States at present; is how to meet with such everincreasing risk of liability? Space insurance, despite all its drawbacks, is considered as the major mechanism available for discharging liability arising out of space disasters. Hence, space liability insurance as a requirement for grant of licence is found in almost all existing national space legislation. However, this paper argues against it, and looks into the feasibility of establishing space liability fund as an alternative to strike balance between the interests of different stakeholders.
\end{abstract}

Keywords: Insured; Insurer; Risk; Space liability fund; Subrogation.

\section{Introduction}

Space era started with the State oriented scientific activities and subsequently, shifted to private sector oriented commercial activities. However, the five major international treaties governing the outer space $^{1}$ are entered during 1960 s and $70 \mathrm{~s}$, which was the era of State oriented space activities. Hence, the norms of liability in these treaties focus on the liability of 'launching State/s' for any damage caused by space activities. This situation continued to exist even after the entry of private sector into the realm of space activities, since the progressive development of space law in the international level halted after the 1979 Moon Agreement. $^{2}$ Therefore, the crucial question for consideration is; how far it is justified to allow the private sector to reap the benefits of space activities and ultimately shift the burden of liability on the State/s for damage caused by its space activities?

\footnotetext{
*LL.M., Ph.D. Professor of Law, Coordinator - Society for Studies in Outer Space Law, The WB National University of Juridical Sciences, Salt Lake, Kolkata, India. Member, International Institute of Space Law (IISL), France. Email: sandeep_nls@yahoo.com.

${ }^{1}$ Treaty on Principles Governing the Activities of States in the Exploration and Use of Outer Space, including the Moon and Other Celestial Bodies, 27 January, 1967 (hereinafter Outer Space Treaty); Agreement on the Rescue of Astronauts, the Return of Astronauts and the Return of Objects Launched into Outer Space, 22 April 1968 (hereinafter Rescue Agreement); Convention on International Liability for Damage Caused by Space Objects, 29 March 1972 (hereinafter Liability Convention); Convention on Registration of Objects Launched into Outer Space, 14 January 1975 (hereinafter Registration Convention); Agreement Governing the Activities of States on the Moon and Other Celestial Bodies, 18 December 1979 (hereinafter Moon Agreement).

${ }^{2}$ See generally Tronchetti (2010). See also Davis \& Lee (1999).
} 
In light of the above concern, the States have started to insist for insurance coverage to shoulder the burden of liability for damage caused by the private space activities. The initial refusal of insurers to shoulder enormous risk associated with the space activities has been overcome with coinsurance and reinsurance techniques. However, neither coinsurance nor reinsurance works smoothly, since both bank on the cooperation between multiple profit-oriented commercial entities, which are hard to find in practical terms.

Apart from the problems between the insurance providers, the issues arising out of conflicting interests of insurers and insured are standing as impediments in the way of hassle-free space insurance. In the present era of competition driven space industry, every space operator is keen on cutting down his cost of operation to remain competitive in the market. So the operator would be in search of insurance coverage with lower premiums but at the same time not something less effective to cater to his needs. Insurer, on the other hand, would face difficulty in providing such cost effective insurance coverage due to enormous risk involved in space activities. Catastrophic damage is a matter of seconds in the space activities. The disasters in 1980s and Columbia disaster in the twenty first century have got chilling effects on space insurance. It is also to be noted that space insurance has a close nexus with the catastrophic disasters (like 9/11) in the aviation sector. ${ }^{3}$ With every such incident, the space insurance market is structurally changing to meet fresh challenges, thereby affecting the relative position of insurer and insured.

In light of the above aspects, the present paper first delves into the issue of liability for private space activities. Then it goes on to outline the current position of space insurance as a requirement in different countries. The specific problems faced by both the insurers and insured in the space sector are discussed in the next part. Finally, the paper concludes with suggestions to achieve a balanced regime of space insurance, which can take care of the interests of all stakeholders. An attempt is also made to find out the viability of creating a space liability fund as an alternative/supplementary aspect to space insurance.

\section{Liability for Private Space Activities}

Outer Space Treaty 1967, though entered five decades back, still stands as the magna carta of space law. ${ }^{4}$ While Article VI of the Outer Space Treaty attributes responsibility on the concerned States for all types of space activities (whether public or private), Article VII imposes liability for damage caused by space activities on respective launching State/s. Principle of liability under Article VII of the Outer Space Treaty is further supplemented by the Liability Convention 1972. Under the Liability Convention, the launching State/s is absolutely liable to pay compensation for any damage caused on the surface of the earth as well as to the aircraft in flight. ${ }^{5}$ Similarly, if the damage is caused elsewhere than on the surface of the earth by a space object of one State to a space object or to persons or

\footnotetext{
${ }^{3}$ Petras (2007) at 323 .

${ }^{4}$ Qizhi (1997) at 93.

${ }^{5}$ Liability Convention, art. II.
} 
property on board such space object of another State, the liability for damage between two States involved is determined on the basis of fault. ${ }^{6}$

The Convention also attributes joint and several liability on multiple launching States in two circumstances: First, where there is a collision between the space objects of two or more launching States, which ultimately cause damage to person or property of yet another State ${ }^{7}$, and second, when two or more States have jointly launched the space object that has caused damage to another State ${ }^{8}$. A launching State that has paid full compensation under joint and several liability principles is entitled to receive reimbursement/indemnification from other launching States on the basis of extent of their fault, or on the basis of prior existing agreement on apportionment of liability. ${ }^{9}$

Thus, the space treaties speak solely about the liability of launching State/s and not about the private players. The definition of launching State provided under the Liability Convention ${ }^{10}$ is also wide enough to attribute one or more launching State/s with respect to each private space launch. This leads to the obvious conclusion that for any damage caused by the private space activities, launching State/s would be liable to pay compensation. Moreover, under Article VI of the Outer Space Treaty, the State/s would also shoulder the burden of international responsibility for private space activities. Added to this, neither State responsibility nor international liability under the space treaties can be avoided by the States even in case of absence of their wrongfulness. ${ }^{11}$ These attributes of State responsibility and international liability for private space activities have posed difficulties to the States in the present era of increasing private space investments.

Imposition of liability on the States for damage caused by the private space activities would mean that the public money would be used for payment of compensation for damage arising out of private activities. This goes against the principles of justice and equity especially in light of the fact that the private players would solely reap benefits out of their space activities and point towards their States when the question of liability arises for any damage caused by their space activities. As we know, one of the well-established tenets of equity is that one who reaps benefits must also incur burden. ${ }^{12}$ Failure to adhere to this principle results in compromising the public good for furthering the private interest in space activities. In order to set right this conundrum that has arisen out of the exponential growth of private space activities, States across the globe have insisted the private space actors to procure minimum insurance coverage to meet with the liability for damage caused by their activities.

\footnotetext{
${ }^{6}$ Liability Convention, art. III.

${ }^{7}$ Liability Convention, art. IV.

${ }^{8}$ Liability Convention, art. V.

${ }^{9}$ Liability Convention, art. IV (2) \& V (2) respectively.

${ }^{10}$ Art. I (c) states: The term "launching State" means: (i) A State which launches or procures the launching of a space object; and (ii) A State from whose territory or facility a space object is launched.

${ }^{11}$ Hermida (1997) at 62.

${ }^{12}$ Bhat \& Bhat (2010)) at 146
} 


\section{Space Liability Insurance and its Current Position}

Space insurance as a mechanism to shoulder the liability originated in 1965 catering to the third party liability and damage to satellites. ${ }^{13}$ It gained prominence during early 1980s when the commercial satellite industry increasingly resorted to space insurance. However, the United States proclamation of Strategic Defense Initiative in $1983^{14}$, and satellite disasters in mid $1980 \mathrm{~s}^{15}$ have resulted in the collapse of space insurance industry. ${ }^{16}$ This has significantly reduced the number of space insurance providers and increased the premiums by manifold. Subsequently in 1990s, attempts were made to reconstruct the space insurance industry and to restore competition. These efforts were quite successful with the cooperation of insurance companies and resulted in the restoration of healthy competition. Consequently, insurance premiums were reduced to make it affordable to private space actors.

High risk involved in space activities was negotiated by adopting coinsurance and reinsurance techniques especially through the pooling arrangements. While coinsurance involves the joining of several insurance providers to proportionately cover the risk according to their affordability ${ }^{17}$, reinsurance involves the spreading of the burden of coverage provided by one insurer to several other players by way of insurer going for further insurance of his interests with other insurers ${ }^{18}$. Such cooperation between the insurance providers not only resulted in providing space liability insurance coverage but also in satellite insurance and launch vehicle insurance. ${ }^{19}$

Requirement of insurance coverage for shouldering the first tier of liability for private space activities can commonly be seen in the existing national space legislation. The United States laws require maximum $\$ 500$ million insurance coverage for third party liability and $\$ 100$ million insurance coverage to meet claims from government for damage caused to it by private space activities. ${ }^{20}$ In case of any liability, this first tier of compensation by the insurance provider would be exhausted before proceeding to the second tier of payment by United States government subject to a limit of $\$ 1.5$ billion. Australia insists for an insurance coverage of not less than the lesser amount of $\$ 750$ million and maximum probable loss determined as per the regulations. ${ }^{21}$ Austria insists for a minimum insurance coverage of Euro 60 million. ${ }^{22}$ South Korea caps the

\footnotetext{
${ }^{13}$ van Reeth (1984) at 127.

${ }^{14}$ Popularly known as Star War programme, is designed to develop a space-based anti-ballistic missile system. For details see Reiss (1992).

${ }^{15}$ Destruction of Cosmos 1402 in 1983 and Challenger in 1986 are two examples of such disasters. Added to this, Palapa B2, Westar VI and Intelsat IV missions were lost during the same period. See Manikowski \& Weiss (2007).

${ }^{16}$ Hermida (2010) at 112.

${ }^{17}$ See Rokas (2008) at 54. See also Ratliff \& Tupper (1990).

${ }^{18}$ See Wehrhahn (2009). See also Carranza-Kopper (2010) at 227.

${ }^{19}$ Satellite insurance and launch vehicle insurance are again divided into pre-launch, launch and satellite/launch vehicle life insurance.

${ }^{20} 51$ U.S.C. $\$ 50914(\mathrm{a})(3)(\mathrm{A})$.

${ }^{21}$ Space Activities Act $1998 \S 48(3)$.

${ }^{22}$ Austrian Outer Space Act $2011 \S 4(4)$.
} 
limit of liability of private space actors at 200 billion Won, which can be subject to insurance coverage. $^{23}$

States like United Kingdom, France, Netherlands, Russia, China, Japan, Singapore and Hong Kong have also come out with the liability insurance requirements. However, they have not specified the amount of insurance coverage to be procured by the space actors in their legislation. ${ }^{24}$ In the absence of specifications, the licensing authorities established under the laws are having the discretion to prescribe the requirement of insurance coverage in specific space activities. United Kingdom ${ }^{25}$ and French authorities have set the insurance coverage limit of Euro 60 million. ${ }^{26}$ Japan, Hong Kong and Singapore require an insurance coverage of $\$ 100$ million. $^{27}$

It is pertinent to note that some of the States have also attempted to ensure that the insurance companies would not try to escape from liability after assuring the coverage. This is very significant because the usual tendency of insurance providers is to ensure coverage at the time of entering into the contract of insurance, and subsequently, when the question of liability arises, they try to avoid it by invoking certain escape clauses. This stands as a serious problem in case of space liability especially because of the possibility of catastrophic damage affecting large number of people. With the legislative or administrative control over insurance companies, such kind of possible misuses can be prevented. Russia, for example, requires the insurance coverage to be obtained either by transmitting insurance premiums to Russian Space Fund or other insurance companies which have obtained licence for space insurance. ${ }^{28}$

\section{Areas of Concerns in Space Liability Insurance}

Even though the world community seems to embrace insurance to offset the risk of space liability, it cannot be considered as the best and infallible mechanism. There are many practical concerns in the space liability insurance. One of the most significant problems faced by the insurance industry is the lack of expertise in the risk evaluation for space activities. Every insurance coverage is dependent on the evaluation and balancing of risk and return factors. ${ }^{29}$ While the high premiums charged for space insurance undoubtedly yield high returns, uncertainties associated with the risks posed by space activities stand as impediments in providing space insurance. Undoubtedly, a successful space venture is capable of earning huge amount of profits to the space actor, and thereby, the insurance provider would also be in an advantageous position. However, the line of distinction between the success and failure in space activities is very thin, which is

\footnotetext{
${ }^{23}$ Space Liability Act 2008 art's 5 \& 6. See Dempsey (2016) at 31.

${ }^{24}$ See for example Outer Space Act 1986 (UK) § 5(2)(f).

${ }^{25} \mathrm{https}$ ///www.gov.uk/government/uploads/system/uploads/attachment_data/file/447278/OSA_ reform_guidance_text_2_.pdf

${ }^{26}$ Gaubert (2012).

${ }^{27} \mathrm{Ibid}$.

${ }^{28}$ Law of Russian Federation about Space Activity 1993, art. 25.

${ }^{29}$ See Bingham (2011).
} 
reflected in the fact that even a pioneer space agency like NASA has lost its missions. ${ }^{30}$ Moreover, the failed missions are capable of ruining the business of not only the space actors but also that of the insurance providers due to their potentiality to cause catastrophic damage. Hence, the insurers would always face dilemma in providing insurance coverage to space industry, which floats on shaky foundations of risks.

The evaluation of risk for providing insurance coverage to space activities is also hampered by the difficulties in discharging the duty to disclose information by the insurance seeker. Duty to disclose in good faith all material information that would be essential for the insurance provider to underwrite the risk is a bedrock principle of contract of insurance. ${ }^{31}$ However, the space activities involve various high-end technologies, which the space actor would like to sacrosanct protect from disclosure. In the absence of such disclosure, the insurance provider can never fully assess the safety of space venture that is sought to be covered by the insurance. A general estimation of risk would also not be possible due to the fact that each space activities are different in nature and operation, and thus, the risks involved in those activities also differ. Added to this, the magnitude of risk is also dependent on another variable, that is, the space capability of the operator concerned.

Despite the resort to coinsurance and reinsurance techniques, the magnitude of risk of damage involved in space activities still stand as deterrent factor for underwriting space liability insurance. Though we are yet to evidence a catastrophic space disaster in terms of third party liability, Cosmos 954 incident has provided us sufficient insight on such a possibility. ${ }^{32}$ The $9 / 11$ incident has further demonstrated the possibility of damage much beyond what can reasonably be expected by the insurance industry to absorb. ${ }^{33}$ In addition, more frequent use of nuclear power sources in space missions have also scaled up the magnitude of risk in space activities. These factors, especially in the absence of reliable mechanism of safety assessment and risk evaluation, have got serious prejudicial effects on space insurance providers.

Space liability insurance seekers also face several difficulties in protecting their interests with insurance coverage. One of the major concerns of insurance seekers is the effect of exclusion clauses that are imposed on them by the insurance providers while underwriting the insurance. Even though there is a requirement of disclosure of exclusion clauses in good faith ${ }^{34}$, often the insurance companies devise the exclusion clauses in such a clever manner that the insurance seekers would not be able to realise the wide range of operation of exclusion clauses. While the defence of material misrepresentation by the insured is invoked quite frequently during the settlement of claims, war risk and nuclear risk exclusion are commonly found inscribed expressly in most insurance policies. ${ }^{35}$ In

\footnotetext{
${ }^{30}$ See generally Lafleur (2010).

${ }^{31}$ Lowry (2009) at 98.

${ }^{32}$ See Cohen (1984) at 85 and 86.

${ }^{33}$ Jerry II (2002) at 101

${ }^{34}$ Schwartz (2008) at 105.

${ }^{35}$ Abeyratne (2003) at 201.
} 
addition, certain grounds of exclusion of coverage found in aviation and other related sectors, like exclusion in case of fault inherent in the project, exclusion of environmental damage, conversion exception ${ }^{36}$ may also be found in space liability insurance.

Insurance contract confers the right of recoupment to insurers under the doctrine of subrogation. ${ }^{37}$ Therefore, a space liability insurance provider may proceed against the insured after the payment of compensation to the victims of accidents. There is also a possibility of the insurer asserting his rights over the space object that has caused damage while exercising the right of recoupment, especially in the circumstances wherein the insurance coverage is obtained for damage to space object as well as third party liability together. This would be detrimental to the interests of the insured, since space objects - whether active or defunct - possess high-end technology and intellectual property rights. Handing over such space object to the insurer would mean free transfer of technology and intellectual property rights, which no reasonable space actor would prefer.

Added to above concerns of insurer and insured, problems may also be faced in the context of duty to mitigate damage, which is one of the essential elements of insurance contracts ${ }^{38}$. This duty, when read in the context of relationship between the insurer and insured, imposes an obligation on the insured to take all reasonable measures to avoid the aggravation of damage arising out of his activities. Upon failure of the insured to take such reasonable measures to mitigate damage, the insurer's liability to pay compensation would be reduced. ${ }^{39}$ Though the onus of proving the failure of insured to take reasonable measures to mitigate damage is on the insurer ${ }^{40}$, it is often found that the insurers have invoked it especially in the cases involving payment of hefty compensation. ${ }^{41}$

As mentioned by Ken Cooper-Stephenson, the defendant needs to prove three factors for a successful claim of mitigation. ${ }^{42}$ When we import these factors to the space liability insurance, the insurer has to establish: (a) steps the insured might have taken to avoid the loss; (b) that it would have been reasonable for the insured to take such action; and (c) the extent to which the loss would have been reduced if the steps had been taken. ${ }^{43}$ Since the duty to mitigate damage banks on the reasonableness standard, critical problems would arise in space insurance. While

\footnotetext{
${ }^{36}$ Riddle (2005) at 419. Though the author referred herein has highlighted the conversion exclusion in light of using aircrafts for unlawful purposes, the same principle may be applicable to those cases wherein the insured alters the status or functions of space object without the consent of insurer.

${ }^{37}$ Tye (1952) at 386.

${ }^{38}$ See Darbishire v. Warran [1963] 3 All ER 310; see also Lombard North Central Plc. v. Automobile World (UK) Ltd. [2010] EWCA Civ. 20.

${ }^{39}$ Fischer (2013) at 90.

${ }^{40}$ See Red Deer College v. Michaels [1976] 2 S.C.R. 324; see also Janiak v. Ippolito [1985] 1 S.C.R. 146.

${ }^{41}$ See for example, Lombard North Central Plc. v. Automobile World (UK) Ltd. [2010] EWCA Civ. 20; Gordon Chem. Co. v. Aetna Cas. \& Sur. Co., 358 Mass. 632, 266 N.E.2d 653 (1971); Northwestern State Portland Cement Co. v. Hartford Fire Ins. Co. 360 F.2d 531 (8th Cir. 1966); and Baxter Inter., Inc. v. American Guarantee and Liability Ins. Co. 861 N.E. $2 d 263$ ( $1^{\text {st }}$ Dist. 2d 2006).

${ }^{42}$ See Cooper-Stephenson (1996) at 868.

${ }^{43}$ Ibid.
} 
reasonableness varies from person to person ${ }^{44}$, repetitive practices are referred by the courts to arrive at conclusions on reasonableness ${ }^{45}$. However, in space activities, such repetitive practices are not found due to the differences in nature and conduct of each space ventures. ${ }^{46}$ Hence, the determination of reasonable measures that could have been taken by the insured to mitigate damage is ultimately dependant on the court's findings on the basis of factors best known to the individual judges concerned. Leaving such an amount of discretion to judges in deciding issues under space insurance, which usually involve high-stakes, would be detrimental to the interests of different stakeholders. It is pertinent to note here that in space liability insurance, the stakeholders involved are not only the insured and the insurer, but also the victims of space accidents. Therefore, allowing the insurer to take the defence of failure of insured to mitigate damage would in turn mean the depravation of rights of third party victims in getting compensation. Moreover, the subjectivity involved in testing the reasonable measures to mitigate damage in space accidents may also take away the essential element of predictability in the process of decision-making, which hits the very basis of justice delivery system. ${ }^{47}$

\section{Conclusion and the Way Forward}

Despite the developments in technology, space activities pose significant risk of damage to those involved in space activities as well as others, who might become third party victims of mishaps. The space treaties, being drafted in the era of State-oriented space activities, impose liability only on States for causing any damage by their space activities. However, with the development of private space activities, applying the same principle of liability to hold the States liable for the misdeeds of private players does not hold well in terms of justice and equity. Without any doubt there is a requirement of reliving States from such unjustifiable burden of liability to prevent the sacrifice of common interest in the zeal of promoting individual interest of private players.

Devising the requirement of space insurance as a mechanism to shift such State liability has been found useful in the recent past. However, it is not certain to work in the long run due to the above discussed concerns in the space insurance. As of now, these problems are not in the limelight due to the absence of any major space disaster. With the increase in space activities and unabated increase in debris creation, the risk of collision in outer space is increasing by manifold. Moreover, the use of nuclear power sources in space activities adds on to the concerns of risk of damage that may be caused by space activities. If the unfortunate event of catastrophe happens in the future, the insurance

\footnotetext{
${ }^{44}$ Moore \& Gaudreau (2013).

${ }^{45}$ Hevia (2013) at 82 .

${ }^{46}$ Dembling (1970) at 88 .

${ }^{47}$ Predictability of judgements as a principle is strongly rooted in common law. See generally Atiyah (1992).
} 
companies concerned would certainly try their best to avoid payment of compensation to the victims by misusing the grey areas of space insurance.

In a high risk venture like space activities, balancing of interests of different stakeholders attains greater significance. Interests of the insurer, insured and third party victims need to be balanced in the space insurance. Given the limited number of space insurance providers, the insurers seem to have an upper hand in tailoring the space insurance policies. The space actors (insured) would in most circumstances have no option but to accept the terms and conditions of insurer. This may not only compromise their interests but also that of third party victims. Hence, in the current scenario, State regulation of space insurance industry is essential to negate the relatively advantageous position of insurers and strike a balance between conflicting interests of stakeholders.

For a long term solution to the space liability concerns, gradual move towards the creation of space liability fund is advisable. Such a fund may operate at both national and international levels. At the national level, analogy can be drawn with the working model of nuclear liability fund created in the United States. PriceAnderson fund created under the Price-Anderson Act 1957 has grown big enough to meet with liability needs arising out of any nuclear disaster in the United States. ${ }^{48}$ Similar attempt has also been done in India under the Civil Liability for Nuclear Damage Act 2010. ${ }^{49}$ In the field of space activities, Russian Federation has already brought in the requirement of establishing Russian Space Fund under its national space legislation. ${ }^{50}$ This Fund may be utilised for payment of compensation in case of damage caused by space activities. ${ }^{51}$ Again in the international level, creation of liability funds can be seen in the nuclear liability regime. Convention on Supplementary Compensation 1997 and Brussels Supplementary Convention 1963 as amended by 2004 Protocol are two major examples of creating international liability fund.

The proposed space liability fund can be created by way of contributions from each space actor, which may be fixed as a certain percentage of profits made out of their space activities. In comparison to space insurance, the space liability fund has its own advantages: First, it would be a permanent fund unlike space insurance, which lapses and has to be obtained separately for each space activity. Second, the space liability fund would be ever-growing with continuing contributions from space actors. In contrast, the space insurance premiums are forfeited after the lapse of insurance period, and therefore, no corpus is created in space insurance. Third, the space liability fund operates on the basis of collective responsibility of space industry to make good the loss caused by individual space activities, which helps in sharing of burden. However, the space insurance is based on individual responsibility of space actor to procure adequate insurance coverage to compensate damage. Fourth, as a logical extension of the above point, the victims of space

\footnotetext{
${ }^{48}$ See Elizabeth \& Bergan (2011) at 279.

${ }^{49}$ Civil Liability for Nuclear Damage Act 2010 § 7 (2) states; "For the purpose of meeting part of its liability under clause (a) or clause (c) of sub-section (1), the Central Government may establish a fund to be called the Nuclear Liability Fund by charging such amount of levy from the operators, in such manner, as may be prescribed."

${ }^{50}$ Law of Russian Federation about Space Activity 1993, art. 13.

${ }^{51}$ Law of Russian Federation about Space Activity 1993, art. 25.
} 
disasters are better assured of compensation in the space liability fund model when compared to space insurance model. This is due to the fact that neither the space actor nor the insurance provider, acting individually, would be capable of compensating catastrophic damage. Even if the insurance companies are adopting the coinsurance and reinsurance techniques, they would not be able to match with the enormous potentiality of space liability fund to absorb liability. A key factor of distinction that may be noted in this regard is that the coinsurance and reinsurance essentially involve many profit-oriented insurance companies and the space liability fund is free from them. Thus, when the element of profit is excluded in the compensation regime, the fund available for compensation would invariably be more.

Finally, the author finds that the space liability fund provides a better protection to victims of space disaster, and also helps the States to shift their onerous burden of liability for private space activities. At the same time, the space actor would not be subject to any additional burden, since the amount that he should have paid as insurance premium might just have to be contributed to the space liability fund. Thus, the space liability fund stands as an interesting option available for rebalancing the interests of different stakeholders in the existing imbalanced space liability regime.

\section{References}

Abeyratne, R. (2003). 'Synergies and Problems in Outer Space Insurance and Air Transport Insurance' in Transp. L.J. 30:189-211.

Atiyah, P. S. (1992). 'Justice and Predictability in the Common Law' in Unsw L.J. 15:448461.

Bhat, B.S. \& Bhat, P.I. (2010). 'Legal Framework of State Responsibility and Liability for Private Space Activities' in Bhat B.S. (ed.) (2010) Space Law in the Era of Commercialisation. Lucknow: Eastern Book Company, at 131-149.

Bingham, R.E. (2011). 'Risk and Return: Underwriting, Investment and Leverage . Probability of Surplus Drawdown and Pricing for Underwriting and Investment Risk'. Available at http://www.casact.org/library/00pcas/bingham.pdf

Carranza-Kopper, E. (2010). 'Fronting Arrangements: Industry Practices and Regulatory Concerns' in Conn. Ins. L.J. 17: 227-252.

Cohen, A.F. (1984). 'Cosmos 954 and the International Law of Satellite Accidents' in Yale J. Int'l L. 10:78-91.

Cooper-Stephenson, K. (1996). Personal Injury Damages in Canada. $2^{\text {nd }}$ ed. Scarborough: Carswell.

Davis, M. \& R.J. Lee (1999). 'Twenty Years after the Moon Agreement and its Legal Controversies" in 1999 Austl. Int'l L.J. 9-32.

Dembling, P.G. (1970). 'Establishing Liability for Outer Space Activities' in Proceedings of the Thirteenth Colloquium on the Law of Outer Space (Constance, Germany, October 4-10, 1970). William S. Hein, Incorporated, 1971, at 87-97.

Dempsey, P.S. (2016). 'National Laws Governing Commercial Space Activities: Legislation, Regulation \& Enforcemen' in Nw. J. Int'l L. \& Bus. 36:1-44.

Fischer, J.M. (2013). 'Does an Insured have a Duty to Mitigate Damages When the Insurer Breaches?' in Conn. Ins. L.J. 20:89-117. 
Gaubert, C. (2012). 'Can space insurance offer workable solutions for outer space sustainability', available at http://iislweb.org/docs/2012_Gaubert.pdf

Hermida, J. (1997). Commercial Space Law: International, National and Contractual Aspects. Buenos Aires: Ediciones Depalma..

Hermida, J. (2010). 'Space Insurance' in Bhat B.S. (ed.) (2010) Space Law in the Era of Commercialisation. Lucknow: Eastern Book Company, at 111-130.

Hevia, M. (2013). Reasonableness and Responsibility: A Theory of Contract Law. Dordtrecht: Springer.

Jerry II, R.H. (2002). 'Insurance, Terrorism, and 9/11: Reflections on Three Threshold Questions' in Conn. Ins. L.J. 9: 95-120.

Lafleur, C. (2010). 'Spacecraft stats and insights' in The Space Review. (Apr. 5, 2010). Available at $\mathrm{http}: / / \mathrm{www}$.thespacereview.com/article/1598/1.

Lowry, J. (2009). 'Whither the Duty of Good Faith in UK Insurance Contracts' in Conn. Ins. L.J. 16: 97-156..

Manikowski, P. \& M.A.Weiss (2007). The Satellite Insurance Market and Underwriting Cycles. Available at http://www.aria.org/meetings/2007papers/IIIB\%20-\%202\%20\%20Mani kowski.pdf.

Moore, S.R. \& S. Gaudreau (2013). 'Mitigation in Personal Injury Cases', http://www.bla ney.com/files/MitigationPersonalInjuryCases_SMoore_SGaudreau_2013.pdf

Petras, C. M. (2007). 'An Alternative Proposal to Modernize the Liability Regime for Surface Damage Caused by Aircraft to Address Damage Resulting from Hijackings or Other Unlawful Interference' in Gonz. J. Int'l L. 10:315-339.

Qizhi, H. (1997). 'The Outer Space Treaty in Perspective' in J. Space L. 25:93-100.

Ratliff, J. \& S. Tupper (1990). 'Competition Law and Insurance: Recent Developments in the European Community' in Int'l Bus. Law 18:352-358.

van Reeth, G. (1984). 'Space and Insurance' in Int'l Bus. Law 12:127-131.

Reiss, E. (1992). The Strategic Defense Initiative. Cambridge: Cambridge University Press,

Riddle, G. H. (2005). 'Aviation Insurance Coverage Issues Beware the Renter Pilot' in $J$. Air L. \& Com. 70:407-428.

Rokas, I. (2008). 'Multi-Jurisdictional Issues - Dealing with Uncertainty in the Insurance Field' in Ins. L.R. 3:54-55.

Schwartz, D. (2008). 'Interpretation and Disclosure in Insurance Contracts' in Loy. Consumer L. Rev. 21:105-154.

Tronchetti, F. (2010). 'The Moon Agreement in the $21^{\text {st }}$ Century: Addressing Its Potential Role in the Era of Commercial Exploitation of the Natural Resources of the Moon and Other Celestial Bodies' in J. Space L. 36:489-524.

Tye, C.W. (1952). 'Salvage and Subrogation Problems' in Ins. L. J. (ii) 386-388.

Wehrhahn, R. (2009). 'Introduction to Reinsurance' in Premier Series on Insurance.2:1-2. http://siteresources.worldbank.org/EXTFINANCIALSECTOR/Resources/2828841242281415644/Introduction_to_Reinsurance.pdf.

Wilson, E. J. \& S Bergan (2011). 'Managing Liability: Comparing Radioactive Waste Disposal and Carbon Dioxide Storage' in Toth, F. L. (ed.) (2011) Geological Disposal of Carbon Dioxide and Radioactive Waste: A Comparative Assessment. Dortrecht: Springer, at 263-294.

http://space.stackexchange.com/questions/1659/what-is-the-success-rate-of-nasa-launches

\section{Treaties}


Agreement Governing the Activities of States on the Moon and Other Celestial Bodies: Dec. 18, 1979 (= Moon Agreement), 18 ILM 1434, 1363 U.N.T.S 3.

Agreement on the Rescue of Astronauts, the Return of Astronauts and the Return of Objects Launched into Outer Space: Apr. 22, 1968 (= Rescue Agreement), 19 U.S.T. 7570, 672 U.N.T.S. 119.

Convention on International Liability for Damage Caused by Space Objects: Mar. 29, 1972 (=Liability Convention), 24 U.S.T. 2389, 961 U.N.T.S. 187.

Convention on Registration of Objects Launched into Outer Space: Jan. 14, 1975 (=Registration Convention), 28 U.S.T. 695, 1023 U.N.T.S. 15.

Treaty on Principles Governing the Activities of States in the Exploration and Use of Outer Space, including the Moon and Other Celestial Bodies: Jan. 27, 1967 (=Outer Space Treaty), 18 U.S.T. 2410, 610 U.N.T.S. 205.

\section{Legislation}

\section{Australia}

Space Activities Act 1998

Austria

Austrian Outer Space Act 2011

India

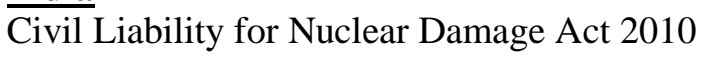

\section{Republic of Korea}

Space Liability Act 2008

\section{Russia}

Law of Russian Federation about Space Activity 1993

$\underline{\text { UK }}$

Outer Space Act 1986

USA

51 U.S.C. $\S 50914(\mathrm{a})(3)(\mathrm{A})$.

\section{Cases}

\section{$\underline{\text { USA }}$}

Baxter Inter., Inc. v. American Guarantee and Liability Ins. Co., 861 N.E. 2 d 263 ( $1^{\text {st }}$ Dist. 2d 2006)

Gordon Chem. Co. v. Aetna Cas. \& Sur. Co., 358 Mass. 632, 266 N.E.2d 653 (1971)

Northwestern State Portland Cement Co. v. Hartford Fire Ins. Co. 360 F.2d 531 (8th Cir. 1966) 


\section{$\underline{\text { UK }}$}

Darbishire v Warran [1963] 3 All ER 310

Lombard North Central Plc. v Automobile World (UK) Ltd. [2010] EWCA Civ. 20

\section{Canada}

Janiak v Ippolito [1985] 1 S.C.R. 146

Red Deer College v Michaels [1976] 2 S.C.R. 324 
